\title{
Hepatitis B infection and preeclampsia among pregnant Sudanese women
}

\author{
Mohamed A. Ahmed', Manal E. Sharif ${ }^{2}$, Duria A. Rayis ${ }^{1}$, Abubakr M. Nasr $^{1}$ and Ishag Adam ${ }^{1 *}$ (D)
}

\begin{abstract}
Background: Previous published studies have reported conflicting results of association between hepatitis B virus (HBV) infection and preeclampsia. There was no published data on HBV and preeclampsia in Africa including Sudan. The aim of the present study was to investigate the association between HBsAg seropositivity and preeclampsia.

Methods: A case -controls study (200 women in each arm) was conducted at Saad Abualila Maternity Hospital, Khartoum, Sudan.

The cases were women with preeclampsia and the controls were healthy pregnant women. Socio-demographic characteristics were gathered using questionnaire and HBsAg was investigated using an ELISA.

Results: There was no significant difference between the cases and the controls in their age, parity, residence, education and blood groups. The majority of the cases were mild preeclampsia (159; 79.5\%).

In comparison with the controls, a significantly higher number of the cases were HBsAg seropositive [30 (15.0\%) vs. $12(6.0 \%), P=0.005]$. In binary regression women with $\mathrm{HBsAg}$ seropositive were at higher risk of preeclampsia than women who were HBsAg seronegative ( $\mathrm{OR}=2.86,95 \%, \mathrm{Cl}=1.41-5.79, P=0.003)$.
\end{abstract}

Conclusion: In the current study HBsAg seropositivity is associated with preeclampsia. Preventive measure should be implemented.

\section{Background}

Preeclampsia is the occurrence of both hypertension (systolic blood pressure $\geq 140 \mathrm{~mm}$ HG or diastolic $\geq 90 \mathrm{~mm}$ HG) and proteinuria in the second half of pregnancy [1]. It has been estimated that there are around 8.5 million cases of preeclampsia reported worldwide annually and preeclampsia complicates around $2-4 \%$ of deliveries $[2,3]$. Preeclampsia/eclampsia is a major health problem worldwide and it is the main cause of maternal and perinatal morbidity and mortality $[2,4]$. Although the exact pathophysiology of preeclampsia is not yet fully understood, it is characterized by widespread maternal endothelial dysfunction which might be triggered by maternal infections. There is a growing body of evidence of association between various bacterial/viral maternal infections and preeclampsia $[5,6]$.

Previous published studies have reported conflicting results of association between maternal hepatitis $B$ virus (HBV) infection and pregnancy induced hypertension.

\footnotetext{
* Correspondence: ishagadam@hotmail.com

${ }^{1}$ Faculty of Medicine, University of Khartoum, P. O. Box 102, Khartoum, Sudan Full list of author information is available at the end of the article
}

While some studies reported a significantly positive association between maternal HBV infection and pregnancy induced hypertension [7], some other authors observed no association or even negative association between HBV and preeclampsia [8-11].

Furthermore most of these studies have been done in USA [12], Europe and South East Asia [10, 11]. To our best knowledge, there was no published data on HBV and preeclampsia in Africa including Sudan. Moreover, the rate /incidence of preeclampsia and HBV varied between different ethnicities and different settings [13, 14]. Unlike the developed countries, the vast majority of African countries characterized by a high HBV disease endemicity [15]. Therefore, the observation of the previous studies might not be generalizable to our setting.

Investigating the association between HBV and preeclampsia is of paramount importance for clinicians and health planners because preventive measures and treatment could be employed to prevent preeclampsia and its undesirable adverse effects.

Preeclampsia/eclampsia is the major health problem and associated with high maternal and perinatal 
mortality in Sudan [16, 17]. Moreover we have previously reported that $(5.6 \%)$ of pregnant Sudanese women were positive for HBsAg [18]. The current study was conducted to investigate the association between HBV and preeclampsia in Khartoum, Sudan.

\section{Methods}

A case -controls study (200 women in each arm) was conducted at Saad Abualila Maternity Hospital, Khartoum, Sudan during the period of February through November 2016.

The cases were women with preeclampsia (blood pressure $\geq 140 / 90 \mathrm{mmHg}$ on 2 occasions, at least $6 \mathrm{~h}$ apart, and proteinuria of $\geq 300 \mathrm{mg} / 24 \mathrm{~h}$ ). The cases were classified as mild and severe preeclampsia which is defined by the occurrence of; blood pressure $\geq 160 / 110 \mathrm{mmHg}$ on 2 occasions, at least $6 \mathrm{~h}$ apart and/ proteinuria of $\geq 5 \mathrm{~g} / 24 \mathrm{~h}$ ), HELLP syndrome "hypertension, proteinuria and presence of hemolytic anemia, elevated liver enzymes and low platelet count" [1].

The controls were pregnant women without hypertensive disorders, nephropathy, or diabetes or any underlying disease. Both the cases and the controls had singleton pregnancy.

After signing an informed consent, medical and obstetrics history (age, parity, and gestational age) were gathered using a questionnaire. Five $\mathrm{mL}$ of blood was withdrawn, allowed to clot, centrifuged and tested for HBsAg using an ELISA (4th generation).

A sample size of 200 women in each arm of the study was calculated guided by the previous rate $(5.6 \%)$ of pregnant Sudanese women were positive for $\mathrm{HBsAg}$ [18]. This sample size have over $80 \%$ power to detect a difference of $5 \%$ at $\alpha=0.05$. We assumed that $10 \%$ of the women might not respond or have incomplete data.

\section{Statistics}

The collected data were analysed using SPSS V.20.0 (SPSS Inc., Chicago, IL, USA). Student's $t$ test and $x^{2}$ tests were used to compare continuous and categorized data respectively between the cases and the controls. Binary regression analyses were performed where preeclampsia was the dependent variable and expected risk factors (age, parity, education, etc.) and HBsAg seropositivity were the independent variables. Odds ratio (OR) with a 95\% confidence interval (CI) was calculated and statistical significance was defined as $P<0.05$.

\section{Results}

There was no significant difference between the cases and the controls (200 women in each arm) in their age, parity, residence, education and blood groups, Table 1.
The majority of the cases had mild preeclampsia (159; $79.5 \%)$.

In comparison with the controls, significantly a higher number of the cases were $\mathrm{HBsAg}$ seropositive [30(15.0\%) vs.12 (6.0\%), $P=0.005]$. HBsAg seropositivity was different between the mild and severe cases [22/159(13.8\%) vs. 8/41(19.5\%), $P=0.461$. None of the cases or the controls had jaundice or treated with antiviral drugs, e.g., nucleoti/side analogues.

In binary regression women with HBsAg seropositive were at higher risk of preeclampsia than women who were $\mathrm{HBsAg}$ seronegative $(\mathrm{OR}=2.86,95 \%, \mathrm{CI}=1.41$ 5.79, $P=0.003)$, Table 2 .

\section{Discussion}

The main finding of the current study was the increased risk (2.86 times) of preeclampsia in HBsAg seropositive women. This is comparable to previous findings where Gargari et al., reported increased risk of pregnancy induced hypertension with maternal HBsAg seropositivity in a case-control study among pregnant Iranian women (450 HBV carriers and equal number of the controls, OR $=4.2,95 \%$ CI: $2.2,8.1$ ) [7].

In contrast two previous large studies were conducted in USA. One of these studies enrolled 297,664 subjects among whom 814 HBV carriers across 37 states using the discharge registry data from 1054 hospitals. Results demonstrated no association between maternal HBV infection and preeclampsia [12]. The other one enrolled 1 , 670, 369 of whom $1458 \mathrm{HBV}$ were carriers and again no significant association was observed between HBV and preeclampsia [19]. Likewise no significant association between maternal HBV infection and the risk of preeclampsia was found in many previous reports from various settings $[8,11,12,20]$. The non-significant association $(\mathrm{OR}=1.03,95 \% \mathrm{CI}$ : $0.78-1.35)$ between HBV infection and preeclampsia was recently reported in a metanalyses of fourteen studies [9].

Table 1 Comparing socio-demographic characteristics between women with preeclampsia and controls in Saad Abualila Hospital, Khartoum, Sudan

\begin{tabular}{llll}
\hline Variable & $\begin{array}{l}\text { Women with } \\
\text { preeclampsia }(N=200)\end{array}$ & $\begin{array}{l}\text { Controls women } \\
(\mathrm{N}=200)\end{array}$ & $P$ \\
\hline Mean (SD) of & & $27.1(5.5)$ & 0.128 \\
Age, years & $27.9(5.2)$ & $1.8(1.7)$ & 0.76 \\
$\begin{array}{l}\text { Parity } \\
\text { Frequency (\%) of }\end{array}$ & $2.1(1.8)$ & $144(72.0)$ & 0.741 \\
$\begin{array}{l}\text { Rural residence } \\
\text { Education }\end{array}$ & $140(70.0)$ & $150(75.0)$ & 0.819 \\
$\leq$ secondary level & $147(73.5)$ & $105(52.5)$ & 0.422 \\
O blood group & $103(51.5)$ & &
\end{tabular}


Table 2 Binary regression analyses of the factors associated with preeclampsia in Saad Abualila Hospital, Khartoum, Sudan

\begin{tabular}{llll}
\hline Variable & Odd s ratio & $95 \%$ confidence interval & $P$ \\
\hline Age & 0.98 & $0.94-1.03$ & 0.669 \\
Parity & 0.90 & $0.78-1.04$ & 0.76 \\
Rural residence & 1.11 & $0.70-1.75$ & 0.643 \\
Education & 1.04 & $0.62-1.75$ & 0.857 \\
$\leq$ secondary level & & & 0.985 \\
O blood group & 0.99 & $0.66-1.48$ & 0.003 \\
HBVs Ag positive & 2.86 & $1.41-5.79$ & \\
\hline
\end{tabular}

Comparatively Lao et al. studied 8634 HBV carriers among 86,537 pregnant women in Hong Kong [18], Their results showed that maternal HBV infection was associated with reduced risk of both pregnancy induced hypertension $(\mathrm{OR}=0.79,95 \% \mathrm{CI}: 0.66,0.95)$ as well as preeclampsia $(\mathrm{OR}=0.71,95 \% \mathrm{CI}: 0.56,0.91)[11]$. Interestingly a negative association between $\mathrm{HBsAg}$ carrier status and gestational hypertension was reported in the same region in a large sample study $(13,792$ women of whom 1340 (9.71\%) were chronic HBsAg carriers) [10]. Furthermore a negative association (odds ratio $=0.77$, 95\% confidence interval, $0.65-0.90, P=0.002$ ) between chronic HBV infection and preeclampsia has been recently documented in a met -analysis which included 11,566 preeclamptic women in South East Asia [21]. Caution should be made when comparing our results with the later studies because of the difference in the study types and the different ethnic groups as well as difference in the immunological reaction to variable infections. Despite meticulous exclusion of confounders in most of these studies, the possibility of the bias still holds. Perhaps the care given to the patients vary from one centre to another or from one disease spectrum to another e.g. hypertensive patients with $\mathrm{HBsAg}$ positive could have been managed in a different settings that were primarily aimed for care of health pregnant women. It seems that the epidemiology and pathophysiology of preeclampsia is different in different regions. Parasitic [22], bacterial [5] and viral infections [23] were observed to be associated with preeclampsia in Sudan.

There are plausible explanations for the association between hepatitis and preeclampsia where previous studies have reported that HBV infection could increase the risk of atherosclerosis [24]. Secondly, preeclampsia (which is characterized by widespread maternal endothelial dysfunction) may be triggered by/result of an imbalance between angiogenic, anti-angiogenic and proangiogenic factors e.g. vascular endothelial growth factor $[25,26]$. A significant association/ correlation between $\mathrm{HBV}$, insulin resistance, thrombocytopenia, obesity and renal injury/proteinuria has recently been reported [27-29]. The interaction between these diseases and
HBV might explain the association between HBV and preeclampsia.

One of the limitations of the current study was that some factors e.g. smoking and alcohol consummation were not investigated. Actually (according to the tradition) we were concerned of participants' co-operation if they were asked about smoking and alcohol consummation and hence invalid results. However, a recent study reported the association between smoking, HBV and preeclampsia [8]. HBV genotype was not determined. It is expected that not only HBV E but also A and D is predominant in Sudan [30]. The enrolled women have different ethnic and genetic background/group which might have effects on both preeclampsia and HBV. Furthermore both HCV and I HIV were not investigated in this cohort of women. We have previously reported low rates of both $\mathrm{HCV}(0.6 \%)$ and $\operatorname{HIV}(1.0 \%)$ among pregnant Sudanese women [18, 31].

\section{Conclusion}

In the current study HBsAg seropositivity is associated with preeclampsia. Preventive measure should be implemented. More research is need.

\section{Acknowledgments \\ Authors wish to thank Mr. Abulla Ahmed Hafaza for his technical assistance.}

\section{Funding}

None of the authors received any fund.

\section{Availability of data and materials}

The datasets used and/or analyzed during the current study available from the corresponding author on reasonable request.

\section{Authors' contributions}

MAA and IA coordinated and carried out the study. MES, DAR and AMN conducted the clinical work. MAA, DAR and IA participated in the statistical analysis. All the authors have read and approved the final version of this manuscript.

Ethics approval and consent to participate

The study received ethical clearance from the Research Board at the Department of Obstetrics and Gynecology, Faculty of Medicine, University of Khartoum, Sudan.

\section{Consent for publication}

Not applicable.

\section{Competing interests}

The authors declared that they have no competing interests.

\section{Publisher's Note}

Springer Nature remains neutral with regard to jurisdictional claims in published maps and institutional affiliations.

\section{Author details}

${ }^{1}$ Faculty of Medicine, University of Khartoum, P. O. Box 102, Khartoum,

Sudan. ${ }^{2}$ Faculty of Medicine Al-Neelain University, Khartoum, Sudan. 
Received: 30 October 2017 Accepted: 9 January 2018 Published online: 22 January 2018

\section{References}

1. American College of Obstetricians and Gynecologists. ACOG practice bulletin. Diagnosis and management of preeclampsia and eclampsia. Number 33, January 2002. American College of Obstetricians and Gynecologists. Int J Gynaecol Obstet. 2002;77:67-75.

2. Lo JO, Mission JF, Caughey AB. Hypertensive disease of pregnancy and maternal mortality. Curr Opin Obstet Gynecol. 2013;25:124-32. Available from: http://content.wkhealth.com/linkback/openurl?sid=WKPTLP: landingpage\&an=00001703-201304000-00006.

3. Abalos E, Cuesta C, Grosso AL, Chou D, Say L. Global and regional estimates of preeclampsia and eclampsia: a systematic review. Eur J Obstet Gynecol Reprod Biol. 2013;170:1-7. Available from:

http://linkinghub.elsevier.com/retrieve/pii/S0301211513001966.

4. Abalos E, Cuesta C, Carroli G, Qureshi Z, Widmer M, Vogel JP, et al. Pre-eclampsia, eclampsia and adverse maternal and perinatal outcomes: a secondary analysis of the World Health Organization multicountry survey on maternal and newborn health. BJOG. 2014:14-24. Available from: http://doi.wiley.com/10.1111/1471-0528.12629.

5. Nourollahpour Shiadeh M, Behboodi Moghadam Z, Adam I, Saber V Bagheri M, Rostami A. Human infectious diseases and risk of preeclampsia: an updated review of the literature. Infection. 2017;45:589-600. Available from: http://link.springer.com/10.1007/s15010-017-1031-2.

6. Rustveld LO, Kelsey SF, Sharma R. Association between maternal infections and preeclampsia: a systematic review of epidemiologic studies. Matern Child Health J. 2008;12:223-42. Available from: http://www.ncbi.nlm.nih.gov/pubmed/17577649.

7. Saleh-Gargari: The Association of Maternal HBsAg... - Google Scholar Available from: https://scholar.google.com/scholar_lookup?title=The +Association+of+Maternal+HBsAg+Carrier+Status+and+Perinatal +Outcome\&author=Gargari\&publication_year=2009.

8. Huang X, Tan H, Li X, Zhou S, Wen SW, Luo M. Maternal Chronic HBV infection would not increase the risk of pregnancy-induced hypertension-results from pregnancy cohort in Liuyang rural China. Roques P, editor. PLoS One. 2014;9: e114248. Available from: http://dx.plos.org/10.1371/journal.pone.0114248.

9. Keramat A, Younesian M, Gholami Fesharaki M, Hasani M, Mirzaei S, Ebrahimi E, et al. Inactive hepatitis B carrier and pregnancy outcomes: a systematic review and meta-analysis. Iran J Public Health. 2017;46:468-74. Available from: http://www.ncbi.nlm.nih.gov/pubmed/28540262.

10. To WWK, Cheung W, Mok K-M. Hepatitis B surface antigen carrier status and its correlation to gestational hypertension. Aust. N. Z. J. Obstet. Gynaecol, Available from. 2003;43:119-22. http://www.ncbi.n/m.nih.gov/pubmed/14712966.

11. Lao TT, Sahota DS, YKY C, Law LW, Leung TY. Maternal hepatitis B surface antigen status and incidence of pre-eclampsia. J Viral Hepat. 2013;20:343-9. Available from: http://doi.wiley.com/10.1111/jvh.12037.

12. KLB R, Jhaveri R, Gandhi M, James AH, Swamy GK. Pregnancy outcomes associated with viral hepatitis. J Viral Hepat. 2011;18:e394-8. Available from: http://www.ncbi.nlm.nih.gov/pubmed/21692952.

13. Gong J, Savitz DA, Stein CR, Engel SM. Maternal ethnicity and pre-eclampsia in New York City, 1995-2003. Paediatr Perinat Epidemiol. 2012;26:45-52. Available from: http://doi.wiley.com/10.1111/j.1365-3016.2011.01222.x.

14. Ji Z, Wang T, Shao Z, Huang D, Wang A, Guo Z, et al. A population-based study examining hepatitis $B$ virus infection and immunization rates in Northwest China. Khudyakov YE, editor. PLoS One. 2014;9:e97474. Available from: http://dx.plos.org/10.1371/journal.pone.0097474.

15. Hou J, Liu Z, Gu F. Epidemiology and Prevention of hepatitis B virus infection. Int J Med Sci. 2005;2:50-7. Available from: http://www.ncbi.nlm. nih.gov/pubmed/15968340.

16. Ali AA, Okud A, Khojali A, Adam I. High incidence of obstetric complications in Kassala hospital. Eastern Sudan J Obstet Gynaecol. 2012;32:148-9. Available from: http://www.scopus.com/inward/record.url?eid=2-s2.084856659355\&partnerlD=tZOtx3y1.

17. Ali AAA, Rayis DA, Abdallah TM, Abdullahi H, Adam I. Hypertensive disorders in pregnancy in Kassala Hospital, Eastern Sudan. Khartoum Medical JOurnal 2011;4:656-659.

18. Elsheikh RM, Daak AA, Elsheikh MA, Karsany MS, Adam I. Hepatitis B virus and hepatitis C virus in pregnant Sudanese women. Virol J. 2007:4:104. Available from: http://www.ncbi.nlm.nih.gov/pubmed/17958904.
19. Connell LE, Salihu HM, Salemi JL, August EM, Weldeselasse H, Mbah AK. Maternal hepatitis B and hepatitis C carrier status and perinatal outcomes. Liver Int. 2011;31:1163-70. Available from: http://doi.wiley.com/10.1111/j. 1478-3231.2011.02556.x.

20. Stokkeland K, Ludvigsson JF, Hultcrantz R, Ekbom A, Höijer J, Bottai M, et al. Pregnancy outcome in more than 5000 births to women with viral hepatitis: a population-based cohort study in Sweden. Eur J Epidemiol. 2017;32:617-25. Available from: http://link.springer.com/10.1007/s10654-017-0261-z.

21. Huang Q-T, Chen J-H, Zhong M, Hang L-L, Wei S-S, Yu Y-H. Chronic hepatitis B infection is associated with decreased risk of preeclampsia: a meta-analysis of observational studies. Cell Physiol Biochem. 2016;38:1860-8. Available from: http://www.karger.com/?doi=10.1159/000445548.

22. Adam I, Elhassan EM, Mohmmed AA, Salih MM, Elbashir MI. Malaria and pre-eclampsia in an area with unstable malaria transmission in Central Sudan. Malar. J. BioMed Central Ltd. 2011;10:258. Available from: http://www.malariajournal.com/content/10/1/258.

23. Alshareef SA, Eltom AM, Nasr AM, Hamdan HZ, Adam I. Rubella, herpes simplex virus type 2 and preeclampsia. Virol J. 2017;14.

24. Ishizaka N, Ishizaka Y, Takahashi E, Toda Ei E, Hashimoto H, Ohno M, et al. Increased prevalence of carotid atherosclerosis in hepatitis B virus carriers. Circulation. 2002;105:1028-30. Available from: http://www.ncbi.nlm.nih.gov/pubmed/11877348

25. HIROKOSHI K, MAESHIMA Y, KOBAYASHI K, MATSUURA E, SUGIYAMA H, YAMASAKI Y, et al. Increase of serum Angiopoietin-2 during pregnancy is suppressed in women with preeclampsia. Am. J. Hypertens.2005;18:1181-8. Available from. http://www.ncbi.nlm.nih.gov/pubmed/16182107.

26. Levine RJ, Maynard SE, Qian C, Lim K-H, England LJ, Yu KF, et al. Circulating Angiogenic factors and the risk of preeclampsia. N Engl J Med. 2004;350: 672-83. Available from: http://www.ncbi.nlm.nih.gov/pubmed/14764923.

27. Joo E-J, Chang Y, Yeom J-S, Lee Y-G, Ryu S. Hepatitis B infection is associated with an increased incidence of thrombocytopenia in healthy adults without cirrhosis. J Viral Hepat. 2017;24:253-8. Available from: http://www.ncbi.nlm.nih.gov/pubmed/27860000.

28. Chien C-H, Chen L-W, Lin C-L, Chang S-W, Shyu Y-C, Chen K-F, et al. Unawareness of hepatitis B virus infection confers on higher rate of metabolic syndrome: a community-based study. Sci Rep. 2017;7:9869. Available from: http://www.ncbi.nlm.nih.gov/pubmed/28852048.

29. Shah AS, Amarapurkar DN. Spectrum of hepatitis B and renal involvement. Liver Int. 2018;38:23-32. Available from. http://www.ncbi.nlm.nih.gov/pubmed/28627094.

30. Yousif M, Mudawi H, Hussein W, Mukhtar M, Nemeri O, Glebe D, et al. Genotyping and virological characteristics of hepatitis B virus in HIV-infected individuals in Sudan. Int J Infect Dis. 2014;29:125-32. Available from: http://www.ncbi.nlm.nih.gov/pubmed/25449246.

31. DEA G, Nasr AM, Homeida SM, Elsheikh MA, Adam I. Prevalence of HIV infection among pregnant women of the Central Sudan. J Med Virol. 2006;78

\section{Submit your next manuscript to BioMed Central and we will help you at every step:}

- We accept pre-submission inquiries

- Our selector tool helps you to find the most relevant journal

- We provide round the clock customer support

- Convenient online submission

- Thorough peer review

- Inclusion in PubMed and all major indexing services

- Maximum visibility for your research

Submit your manuscript at www.biomedcentral.com/submit
) Biomed Central 